\title{
Expression of HLA-G and its receptors in relation to transplant acceptance
}

\author{
Stephen E Christmas* \\ Department of Clinical Infection, Microbiology and Immunology, Institute of Infection and Global Health, University of Liverpool, UK
}

Following its initial description in 1990 [1], the non-classical class I HLA molecule HLA-G has been well-characterised on extravillous cytotrophoblast as a molecule intimately involved in protection of the foetus from attack by the maternal immune system [2]. In addition to its expression on trophoblast, HLA-G is also found at lower levels in thymus, cornea, nail matrix, haematopoietic progenitors and pancreas [3], where its function is less clear. Unlike classical class I HLA molecules, HLA-G can be expressed as a variety of cell-bound and soluble isoforms [4], including several soluble forms (sHLA-G).

As well as this diversity of protein isoforms, there is additional variation at the genetic level, with several alloantigens being described. Furthermore, 3' untranslated region polymorphisms lead to diversity in levels of HLA-G expression [5]. Particular UTR polymorphisms have been associated with high, intermediate or low levels of HLA-G expression [6,7]. This has been confirmed in a study of plasma levels of sHLA-G in healthy individuals of different HLA-G 3'UTR haplotypes [8], whereas other authors have not found there to be complete correlation between observed sHLA-G levels and predicted levels of expression according to UTR genotype $[9,10]$.

Any functions of HLA-G are dependent upon expression of its cellular ligands. The three well-described ligands are LILRB1/ILT2 and LILRB2/ILT4, inhibitory receptors expressed mainly on monocytic cells [11]. The third ligand for HLA-G, KIR2DL4, is expressed by most natural killer (NK) cells and has features of both activating and inhibitory receptors [12].

As well as having a role in protection of the foetus from maternal immune responses, HLA-G has been reported to be expressed in some tumours, potentially leading to inhibition of anti-tumour responses [13]. It may also have a role in protection of allografts against rejection and there is a correlation between HLA-G levels and organ graft acceptance [14]. A number of viruses have been reported to induce expression of HLA-G as a mechanism of immune evasion [15]. In our earlier work, we reported that human cytomegalovirus (HCMV) was able to induce expression of HLA-G on some leukocyte subsets in healthy subjects [16]. B cells, CD56+ T cells and monocytes were the main cell types affected, with NK cells and both CD4+ and CD8+ T cells less so [16]. Cell surface KIR2DL4 expression on CD56+ T cells was unaffected by CMV but was increased in the presence of IL-2 [16].

HLA-G expression has previously been reported on small subsets of human leukocytes including monocyte/macrophages [3], particularly of the M2 lineage [17], regulatory T cells [18-20] and CD8+ cytotoxic $\mathrm{T}$ cells [21]. In the context of clinical transplantation, increased expression of HLA-G was noted by CD4+ and CD8+ alloreactive T cells in mixed lymphocyte reactions in vitro [22]. In our current report into HLA-G expression by peripheral leucocytes from renal transplant patients, we found that proportions of CD4+ T cells expressing HLA-G were significantly increased in the first few months post transplantation whereas other leucocyte subsets did not show significant changes [23]. This also applied to both CD45RA+, CD45RO+ and CD69+ subsets, indicating that both naïve and activated cells were involved [23].

Most related reports in kidney transplant patients have supported the concept that enhanced cellular and/or soluble expression of HLA-G is beneficial to transplant acceptance [14,24-33]. In one of these studies [32], donor HLA-G types were involved, indicating that either donorderived dendritic cells or structural cells of the kidney or their sHLA-G production were involved. However, one study showed a correlation between HLA-G alleles associated with lower expression and graft acceptance [34] and another showed that HLA-G on CD4+ T cells was a predictor of rejection [35]. Enhanced HLA-G expression on structural cells of the kidney as well as T lymphocytes or dendritic cells [36] would increase inhibition of leukocytes expressing HLA-G ligands and hence potentially inhibit graft rejection. Dendritic cells have been reported to secrete HLA-G following treatment with the immunosuppressive molecule CTLA4-Ig [37].

Our recent report also showed that short-term culture of human leukocytes from healthy subjects in vitro in the presence of therapeutic concentrations of immunosuppressive drugs routinely used to prevent kidney rejection led to significantly increased proportions of HLA-G+ CD56+ T cells and B cells, but not other T cell subsets [23]. There are only limited studies of the effects of immunosuppressants on HLA-G expression. In one report, rapamycin was found to downregulate the HLA-G receptor ILT-2 on dendritic cells but nevertheless induced T cell tolerance [38]. A further report showed that rapamycin enhanced dendritic cell ILT-4 expression, potentially facilitating allograft acceptance [39]. In heart transplant patients, everolimus was associated with sHLA-G expression [40].

Together, these studies suggest that one mechanism of action of current immunosuppressive therapies may be to enhance expression of donor or recipient HLA-G or its receptors. Future studies could usefully address to what extent alloreactive $\mathrm{T}$ cells may be induced to express HLA-G or its receptors as this would potentially allow their inhibition and hence prevention of allograft rejection.

${ }^{*}$ Correspondence to: Stephen E Christmas, Department of Clinical Infection, Microbiology and Immunology, Institute of Infection and Global Health, Ronald Ross Building, 8 West Derby Street, University of Liverpool, L69 7BE, UK, Tel: 0151795 9643; E-mail: sechris@liverpool.ac.uk

Received: December 02, 2019; Accepted: December 12, 2019; Published: December 16, 2019 


\section{References}

1. Ellis SA, Palmer MS, McMichael AJ (1990) Human trophoblast and the choriocarcinoma cell line BeWo express a truncated HLA Class I molecule. J Immunol 144: 731-735. [Crossref]

2. Kovats S, Main EK, Librach C, Stubblebine M, Fisher SJ, et al. (1990) A class I antigen, HLA-G, expressed in human trophoblasts. Science 248: 220-223. [Crossref]

3. Morandi F, Pistoia V (2014) Interactions between HLA-G and HLA-E in Physiological and Pathological Conditions. Front Immunol 5: 394. [Crossref]

4. Park GM, Lee S, Park B, Kim E, Shin J, et al. (2004) Soluble HLA-G generated by proteolytic shedding inhibits NK-mediated cell lysis. Biochem Biophys Res Commun 313: 606-611. [Crossref]

5. Larsen MH, Hviid TV (2009) Human leukocyte antigen-G polymorphism in relation to expression, function, and disease. Hum Immunol 70: 1026-34. [Crossref]

6. Silva MM, Simoes RT, Castelli EC, Mendes-Junior CT, Deghaide NH, et al. (2010) TNF microsatellite alleles may confer protection against the development of lipodystrophy syndrome in Brazilian HIV patients. Int J Immunogenet 37: 379-385.

7. Castelli EC, Veiga-Castelli LC, Yaghi C, Moreau P, Donadi EA (2014) Transcriptional and posttranscriptional regulations of the HLA-G gene. J Immunol Res 2014: 734068. [Crossref]

8. Craenmehr MHC, Haasnoot GW1, Drabbels JJM1, Spruyt-Gerritse MJ1, Cao M1, et al. (2019) Soluble HLA-G levels in seminal plasma are associated with HLA-G 3'UTR genotypes and haplotypes. HLA 94: 339-346. [Crossref]

9. Martelli-Palomino G, Pancotto JA, Muniz YC, Mendes-Junior CT, Castelli EC, et al. (2013) Polymorphic sites at the 3' untranslated region of the HLA-G gene are associated with differential hla-g soluble levels in the Brazilian and French population. PLoS One 8: e71742. [Crossref]

10. Rokhafrooz S, Ghadiri A, Ghandil P, Ghafourian M, Hossaini SH, et al. (2018) Association between HLA-G 14bp Gene Polymorphism and Serum sHLA-G Protein Concentrations in Preeclamptic Patients and Normal Pregnant Women. Immunol Invest 47: 558-568. [Crossref]

11. Allan DS, McMichael AJ, Braud VM (2000) The ILT family of leukocyte receptors. Immunobiology 202: 34-41. [Crossref]

12. Faure M, Long EO (2002) KIR2DL4 (CD158d), an NK cell-activating receptor with inhibitory potential. J Immunol 168: 6208-6214. [Crossref]

13. Bukur J, Jasinski S, Seliger B (2012) The role of classical and non-classical HLA class I antigens in human tumors. Semin Cancer Biol 22: 350-358. [Crossref]

14. Rebmann V, da Silva Nardi F, Wagner B, Horn PA (2014) HLA-G as a tolerogenic molecule in transplantation and pregnancy. J Immunol Res 2014: 297073. [crossref]

15. Carosella ED, Moreau P, Lemaoult J, Rouas-Freiss N (2008) HLA-G: from biology to clinical benefits. Trends Immunol 29: 125-132. [Crossref]

16. Albayati Z, Alyami A, Alomar S, Middleton D, Bonnett L, et al. (2017) The Influence of Cytomegalovirus on Expression of HLA-G and its Ligand KIR2DL4 by Human Peripheral Blood Leucocyte Subsets. Scand J Immunol 86: 396-407. [Crossref]

17. Nunez SY, Ziblat A, Secchiari F, Torres NI, Sierra JM, et al. (2018) Human M2 Macrophages Limit NK Cell Effector Functions through Secretion of TGF- $\hat{I}^{2}$ and Engagement of CD85j. J Immunol 200: 1008-1015. [Crossref]

18. Feger U, Tolosa E, Huang YH, Waschbisch A, Biedermann T, et al. (2007) HLA-G expression defines a novel regulatory Tâ€ cell subset present in human peripheral blood and sites of inflammation. Blood 110: 568-577. [Crossref]

19. Stamou P, Marioli D, Patmanidi AL, Sgourou A, Vittoraki A, et al. (2017) Simple in vitro generation of human leukocyte antigen-G-expressing T-regulatory cells through pharmacological hypomethylation for adoptive cellular immunotherapy against graftversus-host disease. Cytotherapy 19: 521-530. [Crossref]

20. Pankratz S, Ruck T, Meuth SG, Wiendl H (2016) CD4(+)HLA-G(+) regulatory T cells: Molecular signature and pathophysiological relevance. Hum Immunol 77: 727-733. [Crossref]

21. Viganò S, Negrón JJ, Tse S, Chowdhury FZ, Lichterfeld M, et al. (2017) HLA-G+ HIV-1-specific CD8+ T cells are associated with HIV-1 immune control. AIDS 31: 207212. [Crossref]

22. Le Rond S, Le Maoult J, Creput C, Menier C, Deschamps M, et al. (2004) Alloreactive CD4+ and CD8+ T cells express the immunotolerant HLA-G molecule in mixed lymphocyte reactions: in vivo implications in transplanted patients. Eur J Immunol 34: 649-660. [Crossref]
23. Albayati Z, Heyworth S, Moberly J, Hammad A, Christmas SE (2018) Changes in HLA-G expression by leukocyte subsets following renal transplantation and the effect of immunosuppressive drugs on leukocyte HLA-G expression in vitro. OBM Transplantation 2(4): 032.

24. Kaneku H (2006) Detection of soluble HLA-G and its correlation with kidney transplant outcome. Clin Transpl 2006: 447-54. [Crossref]

25. Crispim JC, Duarte RA, Soares CP, Costa R, Silva JS, et al. (2008) Human leukocyte antigen-G expression after kidney transplantation is associated with a reduced incidence of rejection. Transpl Immunol 18: 361-367. [Crossref]

26. Jin HL, Li CR, Xiao L, Shi BY, Cai M, et al. (2012) Clinical relevance of sHLA-Gmediated with better graft acceptance in early posttransplantation. Transplant Proc 44 1259-1261. [Crossref]

27. Ciliao Alves DC, de Oliveira Crispim JC, Castelli EC, Mendes-Junior CT, Deghaide $\mathrm{NH}$, et al. (2012) Human leukocyte antigen-G 3' untranslated region polymorphisms are associated with better kidney allograft acceptance. Hum Immunol 73: 52-59. [Crossref]

28. Poláková K, Bandžuchová H, Žilinská Z, Chreňová S, Kuba D, et al. (2015) Analysis of HLA-G expression in serum and biopsy samples of kidney transplant recipients. Immunobiology 220: 533-537. [Crossref]

29. Hauer V, Risti M, Miranda BLM, da Silva JS, Cidral AL, et al. (2019) The association of HLA-G polymorphisms and the synergistic effect of sMICA and sHLA-G with chronic kidney disease and allograft acceptance. PLoS One 14: e0212750. [Crossref]

30. Durmanova V, Bandzuchova H, Zilinska Z, Tirpakova J, Kuba D, et al. (2019) Association of HLA-G Polymorphisms in the 3'UTR Region and Soluble HLA-G with Kidney Graft Outcome. Immunol Invest 48: 644-658. [Crossref]

31. Rohn H, Schwich E, Tomoya Michita R, Schramm S, Dolff S, et al. (2019) HLA-G 3' untranslated region gene variants are promising prognostic factors for BK polyomavirus replication and acute rejection after living-donor kidney transplant. Hum Immunol S0198-8859: 30660-30663. [Crossref]

32. Janssen M, Thaiss F, Nashan B, Koch M, Thude H (2019) Donor derived HLA-G polymorphisms have a significant impact on acute rejection in kidney transplantation. Hum Immunol 80: 176-183. [Crossref]

33. Okushi Y, Okino K, Mukai K, Matsui Y, Hayashi N, et al. (2017) Circulating and renal expression of HLA-G prevented chronic renal allograft dysfunction in Japanese recipients. Clin Exp Nephrol 21: 932-940. [Crossref]

34. Littera R, Piredda G, Pani A, Frongia M, Onano B, et al. (2013) Role of human leukocyte antigen-G 14-base pair polymorphism in kidney transplantation outcomes. J Nephrol 26: 1170-1178. [Crossref]

35. Lu N, Zhang Y, Zou X, Yang X, Tian J, et al. (2011) HLA-G on peripheral blood CD4(+) T lymphocytes: a potential predictor for acute renal rejection. Transpl Int 24: 1103-11. [Crossref]

36. Amodio G, Comi M, Tomasoni D, Gianolini ME, Rizzo R, et al. (2015) HLA-G expression levels influence the tolerogenic activity of human DC-10. Haematologica 100: 548-557. [Crossref]

37. Bahri R, Naji A, Menier C, Charpentier B, Carosella ED, et al. (2009) Dendritic cells secrete the immunosuppressive HLA-G molecule upon CTLA4-Ig treatment: implication in human renal transplant acceptance. J Immunol 183: 7054-7062. [Crossref]

38. Fedoric B, Krishnan R (2008) Rapamycin downregulates the inhibitory receptors ILT2, ILT3, ILT4 on human dendritic cells and yet induces T cell hyporesponsiveness independent of FoxP3 induction. Immunol Lett 120: 49-56. [Crossref]

39. Stallone G, Pontrelli P, Infante B, Gigante M, Netti GS, et al. (2014) Rapamycin induces ILT3(high)ILT4(high) dendritic cells promoting a new immunoregulatory pathway. Kidney Int 85: 888-897. [Crossref]

40. Sheshgiri R, Gustafsson F, Sheedy J, Rao V, Ross HJ, et al. (2009) Everolimus but not mycophenolate mofetil therapy is associated with soluble HLA-G expression in heart transplant patients. J Heart Lung Transplant 28: 1193-1197. [Crossref]

Copyright: (C2019 Christmas SE. This is an open-access article distributed under the terms of the Creative Commons Attribution License, which permits unrestricted use, distribution, and reproduction in any medium, provided the original author and source are credited. 